\title{
Decreasing Impact of Tomato Production BY INTRODUCING RENEWABLE ENERGY
}

\author{
StAJNKO, D., BERK, P.,VINDIS, P. \& LAKOTA, M.
}

Abstract: The intensification of tomato (Solanum lycopersicum L.) production has led to activities that profoundly influence the ecosystem; therefore, measuring environmental impact is very important. Growing tomato in greenhouse requires a lot of additional heating, which affects the ecological footprint and $\mathrm{CO}_{2}$ emissions significantly. The impact of alternative heating systems was considered for middle European environmental conditions (north-eastern Slovenia) by applying the SPIonWeb ${ }^{\circledR}$ software. The use of alternative heating with geothermal energy as well as wood pellets was found to be alternative for reducing the environmental impact of heating, substantially. By exchanging the ELO with wood pellets for heating PE tunnel, the environmental might be reduced by $61.88 \%$ and by using of geothermal energy instead of natural gas in the glasshouses by the $99.5 \%$.

Key words: tomato, geothermal energy, wood pellets, ecological footprint, Sustainable Process Index
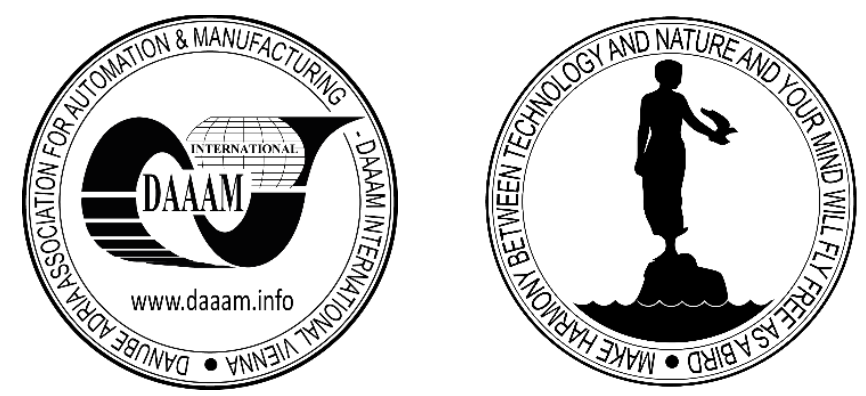

Authors' data: Full Prof. Stajnko, D[enis], Bs. Agric. Eng., Assist. Prof. Berk, P[eter], Ms. Elect Eng., Assist. Prof. Vindis, P[eter], Bs. Agric. Eng., Assoc. Prof. Lakota, M[iran], Bs. Civil Eng. University of Maribor, Faculty of Agriculture and Life Sciences, Pivola 10, SI-2311, Hoče (Maribor), Slovenia, denis.stajnko@um.si, peter.berk@um.si, peter.vindis@um.si miran.lakota@um.si

This Publication has to be referred as: Stajnko, D[enis]; Berk, P[eter]; Vindis, P[eter] \& Lakota, M[iran] (2016). Decreasing Impact of Tomato Production by Introducing Renewable Energy, Chapter 05 in DAAAM International Scientific Book 2016, pp.049-058, B. Katalinic (Ed.), Published by DAAAM International, ISBN 9783-902734-09-9, ISSN 1726-9687, Vienna, Austria

DOI: $10.2507 /$ daaam.scibook.2016.05 
Stajnko, D.; Berk, P.; Vindis, P. \& Lakota, M.: Decreasing Impact of Tomato Produ...

\section{Introduction}

In the last decades, growing demand for fresh, out-of-season tomato (Solanum lycopersicum L.) has motivated many farmers to increase greenhouse-based production in Europe. The tomato can be grown practically the whole year in the greenhouse. However, optimal condition for tomato growth requires daytime temperatures between $27^{\circ} \mathrm{C}$ and $30^{\circ} \mathrm{C}$, and the root temperature not lower than $18^{\circ} \mathrm{C}$ (Dickerson 2011). The high temperature requirement of the tomato has caused different requirements for additional heating across Europe. For this reason, the quantity of energy added into tomato production is very important part of the value chain and subsequently causes great environmental impact.

For this reason, the effect of heating on the environment needs to be addressed by using the life cycle assessment (LCA) principle, which meets this requirement efficiently as it covers most impacts and considers the whole system. LCA is a tool for assessing the potential environmental impact of a production system (Heijungs et al., 1992) that considers the entire life cycle of the product from resource extraction to waste disposal.

One of the tools for estimating LCA of agricultural processes is the ecological footprint (Rees \& Wackernagel 1996), whereby the Sustainable Process Index (SPI), developed by Krotscheck \& Narodoslawsky (1996) is one member of the ecological footprint family; it is based on the concept of "strong sustainability", assuming that a sustainable economy builds only on solar radiation as natural input. Most natural processes are driven by this income and the earth's surface acts as the key resource for the conversion of solar radiation into products and services. Global surface area is, however, a limited resource in a sustainable economy, and anthropogenic as well as natural processes compete for it. Therefore, the area required to embed a certain process sustainably into the ecosphere is a convenient measure for ecological sustainability; the more area a process needs to fulfil a service, the more it "costs" from an ecological sustainability point of view. This evaluation method has been customized for agriculture (Kettl 2013).

Moreover, the ecological footprint GWP (global warming potential) is another important measure for evaluating the impact of processes on the environment. The sum of $\mathrm{CO}_{2}$ life-cycle-emissions and other GWP relevant impacts yields the total GWP measured in $\mathrm{kg} \mathrm{CO}_{2}$ equivalent (Cooper et al., 2011).

In the following chapters we will present the ecological impact of the various heating system in growing fresh tomato, which are most commonly used in Slovenia (middle Europe) today and propose improvements to increase the sustainability of tomato production. A particular focus will be placed on introducing renewable energy into tomato production and its advantages in terms of the footprint and $\mathrm{CO}_{2}$.

\section{SPIonWeb tool}

The SPIonWeb tool (http://spionweb.tugraz.at/) was developed at TU Graz for estimating the ecological footprint, $\mathrm{CO}_{2}(\mathrm{~kg})$ emissions as well as GWP (global warming potential). The ecological footprint of each heating system was estimated by 
including environmental impacts related to fossil- $\mathrm{C}\left(\mathrm{kg} \mathrm{CO}_{2} \mathrm{ha}^{-1}\right)$, air, water, soil, nonrenewable, renewable and area resources.

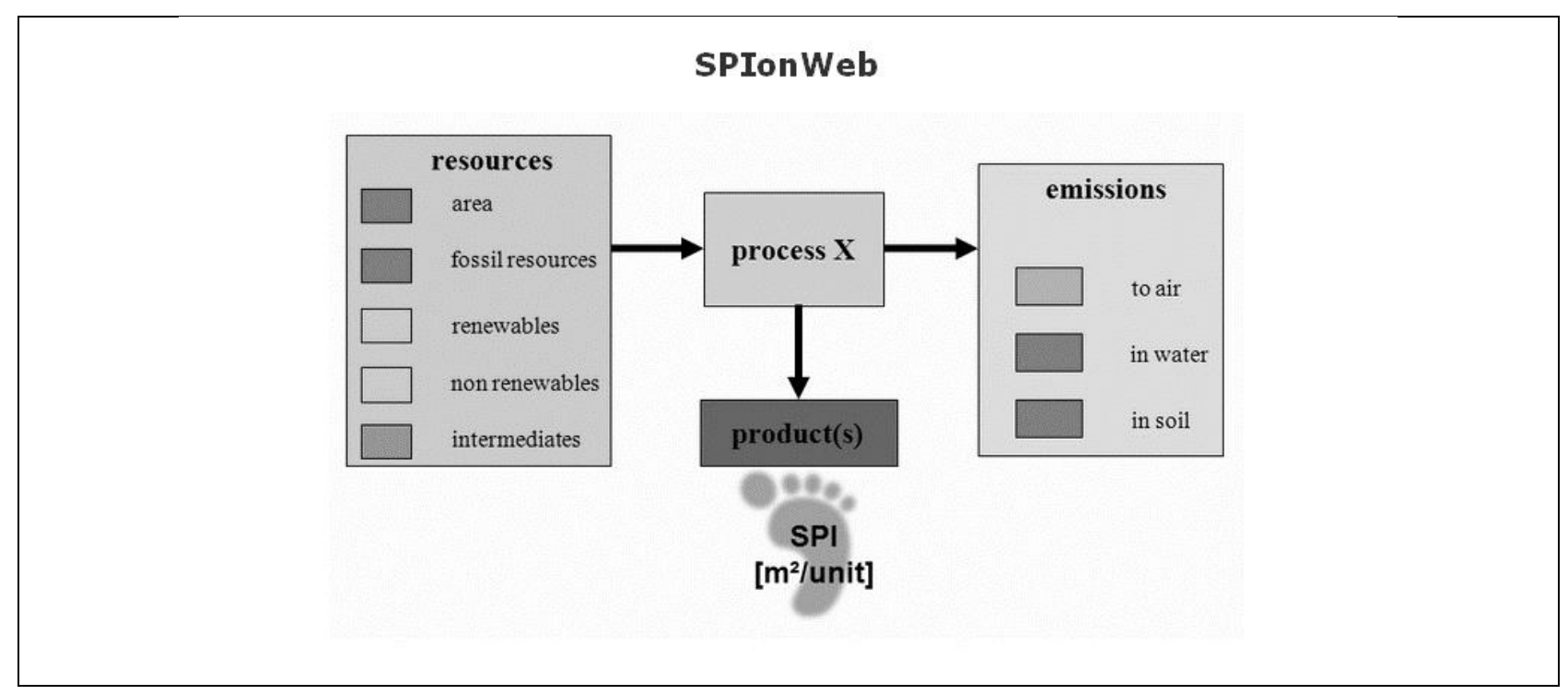

Fig. 1. Ecological footprint scheme based on SPI (Kettl, 2013)

According to SPIonWeb tool calculation of fossil-C assumed sedimentation of carbon to ocean beds, which requires about $500 \mathrm{~m}^{2}$ of sea ground per year to put $1 \mathrm{~kg}$ of carbon back into the long term (fossil) storage of the sea bed. The footprint for emissions to water is based on a replenishment rate, which is based on the precipitation rate in a specific geographic region of the compartment and a natural concentration of the emitted substance. The footprint for emissions to soil is similar to the footprint for emissions to water, and it is calculated based on the regeneration rate of the compartment soil calculated as compost generated from grassland and the natural concentrations of the emitted substances in the top soil.

The footprint for emissions to air does not have a natural replenishment rate as do the other compartments, but the natural emissions of gaseous substances by forests are taken as a reference.

$\mathrm{CO}_{2}(\mathrm{~kg})$ emissions are calculated from the "Area for fossil carbon", where the extracted fossil carbon and carbon based materials are assumed to be oxidized to $\mathrm{CO}_{2}$ over the life cycle and finally to end up as $\mathrm{CO} 2$ emission to the atmosphere.

GWP potentials are calculated on the basis of GWP factors, where material flows of GWP are calculated by multiplying the GWP factor of the components in the flow and their respective inventory. The sum of $\mathrm{CO}_{2}$ life-cycle-emissions and other GWP relevant impacts is the total GWP measured in $\mathrm{kg} \mathrm{CO}_{2}$ equivalent (Kettl, 2013).

\section{Data}

Data for this study was retrieved from interviews with tomato producers locating in northeastern Slovenia and can be adapted to the neighboring countries, thus the reader should be aware that the location of the tomato production is strongly connected with the regional climate and subsequently the estimated footprint and $\mathrm{CO}_{2}$ emissions. 
Stajnko, D.; Berk, P.; Vindis, P. \& Lakota, M.: Decreasing Impact of Tomato Produ...

\subsection{Production systems}

Table 1 lists the main operations production systems analysed in this paper, whereby each system is divided into four basic sub-systems: soil cultivation, weed management, pest (insects and diseases) management and fertilizer application.

\begin{tabular}{|c|c|c|c|c|}
\hline Production system & $\begin{array}{c}\text { Soil } \\
\text { cultivation } \\
\text { and basic }\end{array}$ & Weed management & $\begin{array}{c}\text { Pest } \\
\text { management }\end{array}$ & $\begin{array}{l}\text { Fertilizer } \\
\text { application }\end{array}$ \\
\hline \multirow{4}{*}{$\begin{array}{c}\text { Open field } \\
\text { according to the } \\
\text { Slovene } \\
\text { agriculture act and } \\
\text { GAP }\end{array}$} & Ploughing & $\begin{array}{c}\text { Preventive use of } \\
\text { herbicides }\end{array}$ & $\begin{array}{l}\text { Preventive use of } \\
\text { insecticides }\end{array}$ & NPK and N \\
\hline & \multirow{2}{*}{$\begin{array}{l}\text { Seedbed } \\
\text { preparation }\end{array}$} & $\begin{array}{l}\text { Plants growing on } \\
\text { PE film }\end{array}$ & \multirow{3}{*}{$\begin{array}{c}\text { Fungicides } \\
\text { and fungicides } \\
\text { according to GAP }\end{array}$} & $\begin{array}{l}\text { mineral } \\
\text { added by } \\
\text { irrigation, }\end{array}$ \\
\hline & & \multirow{2}{*}{$\begin{array}{l}\text { Inter-row } \\
\text { harrowing } \\
\text { manually }\end{array}$} & & $\begin{array}{c}\text { analysis and } \\
\text { nutrient }\end{array}$ \\
\hline & Planting & & & removal. \\
\hline $\begin{array}{c}\text { PE tunnel } \\
\text { according to the } \\
\text { Slovene } \\
\text { agriculture act and } \\
\text { GAP }\end{array}$ & $\begin{array}{l}\text { Ploughing, } \\
\text { seedbed } \\
\text { preparation, } \\
\text { planting }\end{array}$ & $\begin{array}{l}\text { Plants growing on } \\
\text { PE film } \\
\text { Inter-row } \\
\text { harrowing } \\
\text { manually }\end{array}$ & $\begin{array}{l}\text { Preventive use of } \\
\text { Pesticides } \\
\text { according to the } \\
\text { rules of INT } \\
\text { management }\end{array}$ & $\begin{array}{l}\text { NPK and N } \\
\text { mineral } \\
\text { Added by } \\
\text { irrigation, } \\
\text { based on soil } \\
\text { analysis and } \\
\text { nutrient } \\
\text { removal }\end{array}$ \\
\hline $\begin{array}{l}\text { Glass greenhouse } \\
\text { according to the } \\
\text { Slovene } \\
\text { agriculture act and } \\
\text { GAP }\end{array}$ & $\begin{array}{l}\text { Hydroponic } \\
\text { growing }\end{array}$ & $\begin{array}{l}\text { Plants growing on } \\
\text { coconut } \\
\text { fibre bed, white PE } \\
\text { wrapped }\end{array}$ & $\begin{array}{l}\text { Use of natural } \\
\text { predators }\end{array}$ & $\begin{array}{c}\text { Soluble } \\
\text { nutrients apply } \\
\text { composted cattle } \\
\text { applied by } \\
\text { irrigation }\end{array}$ \\
\hline
\end{tabular}

Tab. 1. Different tomato systems included in the study.

\subsection{Input processes in different production systems}

Table 2 presented all amounts of materials and machines used on $10,000 \mathrm{~m}^{2}$ of net area in different production systems. Before entering to SPIonWeb the data were calculated per $1 \mathrm{~kg}$ of fresh tomato by dividing with annual yield (Table 3) and the facilities lifetime. On that way, it serves as the basis for the estimation of the process impacts involved in the particular production. 


\begin{tabular}{|c|c|c|c|c|c|}
\hline \multicolumn{6}{|c|}{ Production system } \\
\hline Measures & Input & \begin{tabular}{|l} 
Glass \\
greenhouse
\end{tabular} & PE tunnel & Open field & Unit \\
\hline Ploughing & $50 \mathrm{~kW}$ tractor & 1 & 2 & 2 & $(\mathrm{~h} * * *)$ \\
\hline $\begin{array}{l}\text { Basic } \\
\text { fertilization } \\
\text { (tractor) }\end{array}$ & $50 \mathrm{~kW}$ tractor & I & 1 & 1 & $(\mathrm{~h} *)$ \\
\hline \multirow{9}{*}{ Fertigation } & NPK $(7: 20: 30)$ & I & 500 & 500 & (kg/ha) \\
\hline & Stable manure & I & I & I & (kg/ha) \\
\hline & $\left(\mathrm{CaNO}_{3}\right)$ & 11,000 & 500 & 500 & $(\mathrm{~kg} / \mathrm{ha})$ \\
\hline & $\mathrm{KNO}_{3}$ & 6,600 & & & (kg/ha) \\
\hline & $\mathrm{KCl}$ & 630 & & & $(\mathrm{~kg} / \mathrm{ha})$ \\
\hline & $\mathrm{MgSO}_{4}$ & 4,600 & & & (kg/ha) \\
\hline & NPK (10:5:26) & I & 1,800 & 1,800 & (kg/ha) \\
\hline & $\mathrm{MnSO}_{4}$ & 40 & & & (kg/ha) \\
\hline & $\mathrm{CuSO}_{4}$ & 5 & & & (kg/ha) \\
\hline Planting & $50 \mathrm{KW}$ tractor & 1 & 1 & 1 & $(\mathrm{~h} *)$ \\
\hline \multirow{4}{*}{ Pesticides } & $\begin{array}{l}\text { Confidor SL200 } \\
\text { (Insecticide) }\end{array}$ & 1 & 5.2 & 1 & (1/ha) \\
\hline & Calypso SC480 & & & & $(1 / \mathrm{ha})$ \\
\hline & $\begin{array}{l}\text { Ridomil gold } \\
\text { pepite (Fungic.) }\end{array}$ & 1 & 1 & I & (1/ha) \\
\hline & $\begin{array}{l}\text { Switch® } 62,5 \\
\text { WG (Insecticid) }\end{array}$ & 0.12 & 0.12 & & $(1 / \mathrm{ha})$ \\
\hline Water & & 22,270 & 10,500 & 4,800 & $\mathrm{~m}^{3} / \mathrm{anno}$ \\
\hline Electricity & & 19,800 & 1,080 & 340 & kWh/anno \\
\hline Heating & & 650,000 & 4,200 & & $\mathrm{kWh} / \mathrm{anno}$ \\
\hline Plants & & 11,500 & 80,000 & 80,000 & (pieces/ha) \\
\hline
\end{tabular}

Tab. 2. Inputs and yields for different production systems of tomato (Solanum lycopersicum L.).

Intensity of machinery use: * light, $* * *$ high 
Stajnko, D.; Berk, P.; Vindis, P. \& Lakota, M.: Decreasing Impact of Tomato Produ...

\subsection{Infrastructure}

On the basis of the interviews, it was assumed that the greenhouse structure has a lifespan of 20 years, while their foundations last 30 years. On the other side, the tunnel structure lasts for 10 years, and its LDPE covers are replaced every 7 years, while polypropylene ropes are used yearly to tie up the tomato plants. The lifespan of the irrigation pipes in High Density Polyethylene (HDPE) is 3 years in the open field and 7 years in covered production. The soil protective white LDPE $0.05 \mathrm{~mm}$ (greenhouse) and black LDPE $0.05 \mathrm{~mm}$ is also replaced annually (Berk et al., 2010). Greenhouse production uses modern technology, which is fully automatized and thus requires considerable electricity, heating, water and chemical input. Electrical energy is mainly utilized by drives for opening/closing the roof, for pumps needed to run fertigation and for the automation process itself (Vindiš et al., 2010).

\subsection{Heating system}

The tomato in PE covered tunnels are additionally heated with ELO using a 100 $\mathrm{kW}$ boiler for $4,000 \mathrm{~m}^{2}$; warm air is distributed along the tunnel by a fan jet system, which allows heat to be spread more evenly into the lower part. With proper maintenance, the lifespan of a boiler was assumed 15 years, and that of the PE jet tube system, 7 years (Vindiš et al., 2012). On the other side, the greenhouse (glass covered) is heated by natural gas using a $200 \mathrm{~kW}$ boiler for $4,000 \mathrm{~m}^{2}$ and hot water pipe system. Additionally warm air is distributed beneath the tubes with hydroponically grown tomatoes by a fan jet system. In order to estimate the LCA impact of the heating system with renewable energy sources, two scenarios were foreseen; i) in the PE covered tunnel, the oil boiler (ELO) was replaced by a pellet heating system; ii) in the greenhouse, the gas boiler was exchanged with geothermal water coming from a 1,500 $\mathrm{m}$ deep well and a heat exchanger system.

\section{Results and discussion}

\subsection{Yields}

As seen from Table 3 annual yields of tomato varied significantly among different production systems, i.e. from $495,000 \mathrm{~kg} / \mathrm{ha}$ in glass greenhouse to 127,000 $\mathrm{kg} / \mathrm{ha}$ in open field production. The main reason lies in the energy and nutrition input, which in greenhouses enables the creation of optimal temperature conditions and thus an 11-month growing season and a 9-month harvesting season. The influence of higher cultivation temperatures is especially detectable when comparing open field production to the same technology under PE, where open field production is just less than half of that under PE. Heating is, however, not solely responsible for higher yields if the nutrition level is insufficient, as is evident from Stajnko \& Vindiš, (2013) in organic production under $\mathrm{PE}$, in which higher temperatures increased the yield by only 1.1 $\mathrm{kg} / \mathrm{m}^{2}$ i.e. $19.2 \%$ in comparison to production without heating. 


\begin{tabular}{|l|c|c|c|}
\hline Production system & $\begin{array}{c}\text { Yield } \\
(\mathrm{kg} / \mathrm{ha})\end{array}$ & $\begin{array}{c}\text { Vegetation } \\
\text { period } \\
\text { (months) }\end{array}$ & $\begin{array}{c}\text { Harvesting } \\
\text { period } \\
\text { (months) }\end{array}$ \\
\hline Glass greenhouse - hidroponically & 495,000 & 11 & 9 \\
\hline PE tunnel & 275,000 & 8 & 6 \\
\hline Open field production - not protected & 127,000 & 6 & 4 \\
\hline
\end{tabular}

Tab. 3. Description of production systems included in ecological footprint calculations.

\subsection{Impact of heating in tomato production}

Firstly, it should be underlined that the location of the tomato production is strongly connected with the regional climate, which influences the net need for additional heating. On the other hand, heating impacts are strongly dependent on the energy input required by a particular growing system, as well the energy source used, whereby significantly lower values are calculated for renewable sources.

Table 4 represents the differences in footprint between conventional and alternative heating systems applied in greenhouse, PE tunnel as well as open field condition. As seen, the biggest footprint for heating $\left(78.450 \mathrm{~m}^{2} \mathrm{a} / \mathrm{kg}\right)$ is calculated when natural gas is used for heating the greenhouse. The main reason lies in the amount of $0.129 \mathrm{~m}^{3}$ of natural gas, which is required for production of $1 \mathrm{~kg}$ fresh tomato under northeastern Slovenian climate conditions for keeping greenhouse inside temperature around $25^{\circ} \mathrm{C}$. On the other side, the use of geothermal heating system leaves the smallest ecological footprint $\left(0.377 \mathrm{~m}^{2} \mathrm{a} / \mathrm{kg}\right)$ for $1 \mathrm{~kg}$ of tomatoes $)$, even though the greenhouse 11 -month growing cycle consumes the most heat.

\begin{tabular}{|l|r|r|r|r|r|}
\hline Production system & $\begin{array}{c}\text { Total } \\
\text { footprint } \\
\left(\mathrm{m}^{2} \mathrm{a} / \mathrm{kg}\right)\end{array}$ & $\begin{array}{c}\text { Heating } \\
\text { footprint } \\
\left(\mathrm{m}^{2} \mathrm{a} / \mathrm{kg}\right)\end{array}$ & $\begin{array}{c}\text { Share of } \\
\text { heating } \\
\text { footprint }(\%)\end{array}$ & $\mathrm{CO}_{2}(\mathrm{~kg})$ & $\begin{array}{c}\text { Share of } \\
\mathrm{CO}_{2} \text { due to } \\
\text { heating } \\
(\%)\end{array}$ \\
\hline $\begin{array}{l}\text { Glasshouse- } \\
\text { genthermal }\end{array}$ & 31.681 & 0.377 & 1.19 & 0.0180 & 15.25 \\
\hline $\begin{array}{l}\text { Glasshouse- natural } \\
\text { gas }\end{array}$ & 109.231 & 78.450 & 71.82 & 0.5255 & 81.67 \\
\hline PE tunnel-ELO & 20.290 & 1.749 & 8.62 & 0.0150 & 18.05 \\
\hline PE tunnel-pellets & 19.725 & 0.667 & 3.38 & 0.0025 & 3.54 \\
\hline Open field integrated & 19.406 & - & - & 0.0673 & - \\
\hline
\end{tabular}

Tab. 4. Additional footprint caused by heating in different tomato growing production systems.

For heating PE tunnel with ELO lower environmental impact $\left(1.749 \mathrm{~m}^{2} \mathrm{a} / \mathrm{kg}\right)$ is calculated due to the shorter growing season in comparison to glasshouse, the ecological impact is smaller in comparison with greenhouse, but again depends very much on the energy used as well the yield produced. Thus, heating with wood pellets leaves even smaller environmental impact in the PE tunnel $\left(0.667 \mathrm{~m}^{2} \mathrm{a} / \mathrm{kg}\right)$ production than heating with ELO. 
Stajnko, D.; Berk, P.; Vindis, P. \& Lakota, M.: Decreasing Impact of Tomato Produ...

\section{$4.3 \mathrm{CO}_{2}$ releases caused by heating in tomato production}

$\mathrm{CO}_{2}$ releases caused by heating depends very much on the length of heating season and energy used (Table 4). In the greenhouse production (glass) heating with geothermal energy left only $0.0180 \mathrm{~kg} \mathrm{CO}$ for $1 \mathrm{~kg}$ of fresh tomato, due to the installation impact of drilling the bore and the electricity needed for running the pumps and electronics. But the long lifespan of geothermal heating installation and huge yields reduce the $\mathrm{CO}_{2}$ to $0.018 \mathrm{~kg}$ per $\mathrm{kg}$ fresh tomato. This release is for $0.5075 \mathrm{~kg} \mathrm{CO}_{2}$ smaller in comparison for heating with natural gas. In the PE tunnel production 0.015 $\mathrm{kg}$ of $\mathrm{CO}_{2}$ is released for ELO heating, which is smaller than heating glasshouse due to the very short heating time, which is limited to the first weeks after planting. However, the use of pellet heating might reduce the $\mathrm{CO}_{2}$ release by additional $83.33 \%$ whenever installed in PE tunnel. This fact makes renewable heating sources very attractive for use also in organic production.

\subsection{Life Cycle impact breakdown for different production systems, including heating}

In the Figure 2 the Life Cycle impact of three production system is broken down into most important input categories; application of $\mathrm{N}$-fertilizer, insecticide, net electricity, PE-LD, reminder and ELO. As seen, the use of gas heating affects the Life Cycle impact significantly in greenhouse, so the use of natural gas heating creates the biggest impact $\left(78.45 \mathrm{~m}^{2} \mathrm{a} / \mathrm{kg}\right)$ because it has the longest additional heating season; consequently, this method of heating exceeded all other impacts.

In contrast, in PE tunnel production, the use of ELO heating is not detectable in the impact because it is used for only a few days during vegetation; besides, the yield is much higher than in case of open field production, so this impact is practically negligible. On the other hand, the use alternative energy sources (geothermal energy or pellets) is not detected among the most important impact shares in any mode of production, since the pre-processes in those chains comprise very low impact.

The second most important breakdown detectable category represents PE-LD (polyethylene-low density), which represents the most important material in common tomato production, since it is an integrated part of foils, covers, irrigation pipes and many other small materials needed for proper working of indoor tomato production. The share of PE-LD category is relatively high because of its short life span, which assumed to be only from 3 to 7 years, thus leaving considerable environmental impact. The third caterogy represents production and application of $\mathrm{N}$-fertilizer with irrigation system, whereby considerable environmental impact is due to energy costs of the Haber-Boschovem fixation of air nitrogen into ammonia. The second important reason lies in the huge quantities of nitrogen being applied in industrial tomato production. In the modern hydroponically grown tomato medium voltage net electricity also plays very important environmental category, since the whole electronics and electro installation requires up to $100 \mathrm{kWh}$ per one working hour. 


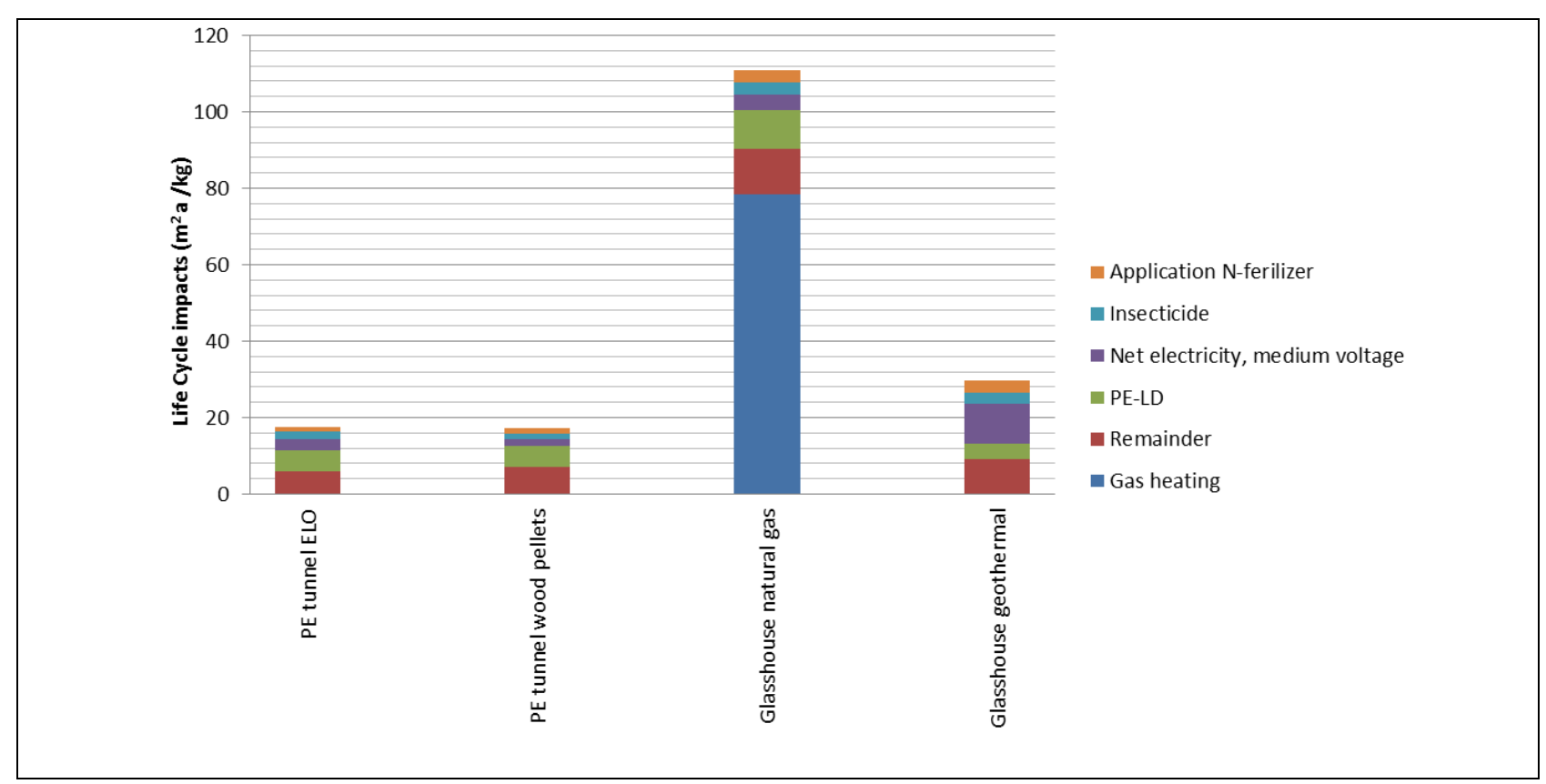

Fig. 2. Life Cycle impact breakdown $\left(\mathrm{m}^{2} \mathrm{a} / \mathrm{kg}\right)$ for different production systems and heating

\section{Conclusion}

Tomato is one of the most important European vegetables which is marketed to consumers practically throughout the year. However, it belongs to the category of warm season vegetables and needs higher temperatures; thus, it is usually grown in a protected area in temperate climates. For this reason, the expected environmental impact and $\mathrm{CO}_{2}$ releases are generally higher than in production of open-field vegetables. However, the lower outdoor temperatures in central Europe can be balanced to some extent by application of alternative renewable energy sources, might significantly affect the environmental impact and $\mathrm{CO}_{2}$ releases.

For instance, the replacement of fossil fuels by geothermal energy can reduce the footprint in greenhouse production to only $0.377 \mathrm{~m}^{2} \mathrm{a} / \mathrm{kg}(0.05 \%)$, while the use of pellets is not beneficial for massive heat demands. However, in PE tunnel and organic production, heating with ELO can be successfully reduced (up to $87.06 \%$ ) by introducing smaller pellet heating systems. In that way, locally produced biomass waste could be efficiently applied and thus help in reducing even the global ecological footprint, since long-distance ELO transport could then be reduced.

\section{Acknowledgements}

This article was created as a result of the applied project CRP V4-1062 entitled "Study of the impact of alternative tillage to improve soil fertility and increase the humus in the soil and reduce $\mathrm{CO}_{2}$ emissions into the atmosphere", which is financed by the Slovenian Research Agency and the Ministry of Agriculture, Forestry and Food of the Republic of Slovenia. 
Stajnko, D.; Berk, P.; Vindis, P. \& Lakota, M.: Decreasing Impact of Tomato Produ...

\section{References}

Berk, P.; Rakun, J.; Vindiš, P.; Stajnko, D. \& Lakota, M. (2010). Temperature loop structure with fuzzy and classical controllers. DAAAM International scientific book 2010, B. Katalinić (Ed.), pp. 117-128., Vienna International Publishing, ISSN 17269687, Vienna

Cooper, J.M.; Butler, G. \& Leifert, C. (2011). Life cycle analysis of greenhouse gas emissions from organic and conventional food production systems, with and without bio-energy options. NJAS - Wageningen Journal of Life Sciences, ISSN: 1573-5214, 58: pp. $185-192$

Dickerson, G. W. (2011). Greenhouse vegetable production. New Mexico State University Extension, 556, http://aces.nmsu.edu/pubs/_circulars/circ556.html [Accessed: 2015-09-29]

Eurostat, Agricultural products (2012).

www.epp.eurostat.ec.europa.eu/statistics_explained/index.php/Agricultural_products. [Accessed: 2014-08-16]

Heijungs, H., Guinée, J.B., Huppes, G., Lankreijer, R.M., Udo de Haes, H.A., Wegener Sleeswijk, A., Ansems, A.M.M., Eggels, P.G., van Duin, R. \& de Goede, H.P. (1992). Environmental life cycle assessment of products: guide and backgrounds (Part 1). Centre of Environmental Sciences, Leiden

Kettl, K.H. (2015). Advanced Sustainable Process Index calculation software, Manual and software structure, Version 1.1. http://spionweb.tugraz.at/SPIonWeb Stepbystep eng.pdf [Accesed on: 2015-09-28] Krotscheck, C. \& Narodoslawsky, M. (1996). The Sustainable Process Index - a new dimension in ecological evaluation. Ecol Eng 6, ISSN: 0925-8574, pp. 241-258

Rees, W. \& Wackernagel, M. (1996). Urban ecological footprints: Why cities cannot be sustainable-And why they are a key to sustainability. Environ Impact Asses Review, 16(4-6), ISSN: 0195-9255, pp. 223-248

Stajnko, D. \& Vindiš, P. (2013). Ecological footprint and fuel consumption under conventional and alternative farming systems. Čeh, B.( Ed.), Dolničar, P. (Ed.), Mihelič, R. (Ed.). = New challenges in agronomy 2013: proceedings of symposium, [Zreče, 2013]. Ljubljana: Slovensko agronomsko društvo, 2013, ISBN: 9789619088470. pp. 253-259

Vindiš, P.; Stajnko, D,: Berk, P. \& Lakota, M. (2010). Qualitative multi-criteria evaluation of energy crops. DAAAM International scientific book 2010, B. Katalinić (Ed.) pp. 99-116, Vienna International Publishing, ISSN 1726-9687, Vienna Vindiš, P.; Lakota, M.; Berk, P. \& Stajnko, D. (2012). Energy efficiency of two types of greenhouses heated by biomass. DAAAM International scientific book 2012, B. Katalinić (Ed.) pp. 157-168, Vienna International Publishing, ISSN 1726-9687, Vienna 